\title{
Evaluation of Optical Radiation from Visual Pathways with Diffusion Tensor Imaging in Patients with Neurofibromatosis
} Type 1

\section{Nörofibromatosis Tip 1'li olgularda Görme Yolaklarından Optik Radyasyonun Difüzyon Tensör Görüntüleme ile Değerlendirilmesi}

(i) Dilek Hacer ÇEŞME

Bezmialem Vakıf University Faculty of Medicine, Department of Radiology, İstanbul, Turkey

\begin{abstract}
Objective: It was investigated whether patients with neurofibromatosis type 1 (NF1) with and without optic glioma (OG) differed from the healthy control group in terms of diffusion tensor imaging (DTI) parameters obtained from optic radiation.
\end{abstract}

Methods: Eighty three patients and 36 healthy controls followed with the diagnosis of NF1 were included in the study. Routine MRI and DTI were applied to all subjects. Fractional anisotropy (FA), mean diffusity (MD), radial diffusity $(\mathrm{RD})$ and axial diffusity $(\mathrm{AD})$ values were calculated by placing $\mathrm{ROI}$ on the right and left optic radiation on colored FA maps. Patients with OG detected by conventional magnetic resonance imaging $(\mathrm{n}=19)$ were classified as group 1, patients with NF1 without OG $(\mathrm{n}=64)$ were classified as group 2 and they were compared with the healthy control group in terms of DTI parameters.

Results: The right and left optic radiation FA values of the patients in group 1 and group 2 were significantly different when compared with the healthy control group. Optical radiation FA values were significantly lower than healthy control group. MD values in group 1 patients with OG were significantly higher than healthy control group. Optic radiation $\mathrm{RD}$ values were significantly higher in group 1 and group 2 compared with healthy control group.

Conclusion: There appears to be microstructural damage in optic radiation in patients with NF1 with or without OG. The idea that

\section{ÖZ}

Amaç: Çalışmamızda, optik gliomu (OG) bulunan ve/veya bulunmayan nörofibromatosis tip 1'li (NF1) olgularda görme yolaklarından optik radyasyondan elde edilen difüzyon tensör görüntüleme (DTG) parametrelerinin sağlıklı kontrol grubu ile farklıık gösterip göstermediğini araşıtırmayı amaçladık.

Yöntemler: NF1 tanısı ile takip edilen 83 olgu ve 36 sağlıklı kontrol çalışmaya dahil edildi. NF1'li olgular ve sağlıklı kontrol grubuna rutin manyetik rezonans görüntüleme ve DTG uyguland. Renkli FA haritalarında sağ ve sol optik radyasyona ROI yerleştirilerek fraksiyonel anizotropi (FA), mean diffusity (MD), radial diffusity $(\mathrm{RD})$ and axial diffusity $(\mathrm{AD})$ değerleri hesaplandı. Konvasiyonel MRG ile OG saptanan olgular ( $\mathrm{n}=19$ ) grup 1, OG bulunmayan NF1'liler ( $\mathrm{n}=64)$ grup 2 olarak sınıflandırılarak sağılık kontrol grubu ile karşılaşııııldı.

Bulgular: Grup 1 ve grup 2 NF1'li olguların sağ ve sol optik radyasyon FA değerleri sağlıklı kontrol grubu ile karşıllaşıırıldığında anlamlı farklılık saptandı. Grup 1 ve grup 2 optik radyasyon FA değerleri kontrollere göre anlamlı derecede düş̧̈ktü. OG bulunan olgularda MD değerleri kontrollere göre anlamlı yüksekti. Grup 1 ve grup 2 olgularda optik radyasyon $\mathrm{RD}$ değerleri kontrollere göre anlamlı yüksekti. Grup 1 ile grup 2 arasında optik radyasyon FA değerleri açısından anlamlı farklılık saptanmadı.

Sonuç: NF 1'li olgularda OG bulunsun veya bulunmasın görme

Address for Correspondence: Dilek Hacer ÇEŞME, Bezmialem Vakıf University Faculty of Medicine, Department of Radiology, İstanbul, Turkey

E-mail: dhcesme@bezmialem.edu.tr ORCID ID: orcid.org/0000-0002-3869-0524 
changes in FA values detected in optic radiation in visual pathways in patients with NF1 can be predicted in the early period of visual impairment is promising in terms of treatment planning and management.

Keywords: Neurofibromatosis type 1, optic gliom, diffusion tensor imaging, fractional anisotropy yolaklarından optik radyasyonda mikroyapısal düzeyde hasarlanma mevcuttur. NF1'li olgularda görme yollarında özellikle optik radyasyonda tespit edilen FA değerlerindeki değişikliklerin gelecekteki görme bozukluğunu erken dönemde tahmin edilebileceği öngörüsü tedavi planlanması ve yönetimi açısından umut vericidir.

Anahtar Sözcükler: Nörofibromatos tip 1, optik gliom, difüzyon tensör görüntüleme, fraksiyonel anizotropi

\section{Introduction}

Neurofibromatosis type 1 (NF1) is an autosomal dominant disease that results in decreased production of neurofibromin, a tumor suppressor protein, due to mutation or deletion in the NF1 gene on chromosome 17. NF1 affects almost all organs and systems in the body. Pigment abnormalities (café-au-lait macules, skinfold frecklings, Lisch nodules), peripheral and central nervous system tumors (neurofibromas and gliomas), learning and attention problems, autism spectrum disorders, bone abnormalities (long bone dysplasias, scoliosis), seizures, sleep disorders, and vasculopathies (moyamoya syndrome, renal artery stenosis) are common in affected patients $(1,2)$.

The incidence of optic glioma (OG) in children with NF1 is approximately $15-20 \%$, and vision loss accompanies up to $35-$ $50 \%(1-4)$. OGs are usually seen in children younger than 7 years old. Determining the timing of treatment of NF1-associated OGs appears to be a clinical challenge. Visual symptoms include loss of visual acuity, proptosis, strabismus, and nystagmus. NF1related OGs are infiltrative and tend to progress along the optic nerves, optic chiasm, optic tract, and optic radiations (5-7). OGs that develop in the optic pathway after the optic chiasm tend to exhibit more aggressive clinical behavior than those involving the optic nerve or chiasm. In patients in whom the optic tract and radiation are affected, visual acuity deficiency is mostly seen. Surgical resection is not very suitable because of the irregular tumor margins of OGs and the risk of vision loss.

A reliable criterion predicting future vision loss in patients requiring treatment has not been defined yet $(1-3,8)$. It is not possible to predict the development of vision loss in patients with NF1 with conventional MRI. There is no relationship between tumor size on MRI and visual impairment (2,7). Diffusion tensor imaging (DTI), an advanced neuroimaging method, shows the relationship between white matter structures and neural functions. Both mean diffusity (MD) and fractional anisotropy (FA) values provide information about microstructural changes in white matter. There are studies advocating that future visual acuity loss can be predicted in NF1-related OG with DTI (2).

In our study, we aimed to investigate whether patients with NF1 with and without OG differed from the healthy control group in terms of DTI parameters in optical radiation of the visual pathways.

\section{Method}

Eighty three patients ( 43 men and 40 women, mean age; 10.51 \pm 5.63$)$ followed with the diagnosis of NF1 and 36 agematched healthy controls (18 men and 18 women, mean age; $10.69 \pm 5.48)$ were included in the study and evaluated retrospectively. Routine MRI and DTI were applied to all patients with NF1 and healthy control group. The following parameters were used in the imaging protocol; axial and sagittal T2 images (TR/TE: 4.280/91 ms matrix: 384×211; NSA: 1; slice thickness $5 \mathrm{~mm}$ ), axial T1 images (TR/TE: 500/87 ms; matrix: 256 $\times 125$; NSA: 1; slice thickness $5 \mathrm{~mm}$ ), axial and coronal FLAIR images (TR/TE/TI: 8,000/118/23.687 ms; NSA: 1; slice thickness $5 \mathrm{~mm}$ ), axial and coronal T1 images with contrast (TR/ TR: 448/ 87; matrix: 256x134; NSA: 1), and 3DT1 postcontrast sagittal images (TR/TE: 476/86; matrix: 256x154; NSA: 1; slice thickness $1 \mathrm{~mm})$. The protocol determined by obtaining DTIs in the axial plane was applied $(\mathrm{TR}=6,000 \mathrm{~ms}, \mathrm{TE}=89 \mathrm{~ms}, 30$ directions, $b=1,000 \mathrm{~s} / \mathrm{mm}^{2}, 5-\mathrm{mm}$ section thickness, $230 \mathrm{~mm}$ FOV and matrix: 128x128). FA, MD, RD (radial diffusity) and $\mathrm{AD}$ (axial diffusity) values were calculated by placing ROI on right and left optical radiation on colored FA maps on a Siemens Leonardo workstation (Figure 1). Patients with NF1 with OG detected by conventional MRI $(\mathrm{n}=19)$ constituted group 1, those with NF1 without OG ( $\mathrm{n}=64)$ constituted group 2; and healthy control group $(n=36)$ were compared in terms of DTI parameters (Figure 2a, b).

\section{Statistical Analysis}

All statistical analyzes were performed with IBM SPSS 19.0. The normal distribution of the groups was evaluated with the Kolmogirov-Smirnov test. Comparisons between patients with NF1 with and without OG and healthy controls were analyzed using the Mann-Whitney $U$ test. A p value less than 0.05 was considered statistically significant.

\section{Results}

Optical radiation $\mathrm{FA}, \mathrm{MD}, \mathrm{AD}$ and $\mathrm{RD}$ values in patients with NF1 with and without OG and in healthy control group are presented in Table 1.

When group 1 and healthy control group were compared;

1- When the right and left optical radiation FA values were compared with the healthy control group, a significant difference 
was found ( $\mathrm{p}=0.0001$ for each). Optic ratio FA values were significantly lower in patients with NF1 with OG compared to healthy controls.

2- Right and left optical radiation MD values were significantly higher than the control group ( $\mathrm{p}=0.02$ and $\mathrm{p}=0.01$, respectively).

3- When the optical radiation $\mathrm{AD}$ values were compared with the healthy control group, no significant difference was found.

4- Right and left optical radiation RD values were significantly higher than the healthy control group (respectively; $\mathrm{p}=0.01$, $\mathrm{p}=0.0001)$.

When group 2 and healthy control group were compared;

1- When the FA values of the right and left optic radiation were compared with the healthy control group, there was a significant difference ( $\mathrm{p}=0.0001$ for each). Optic ratio FA values were significantly lower in patients with NF1 without OG compared to healthy controls.

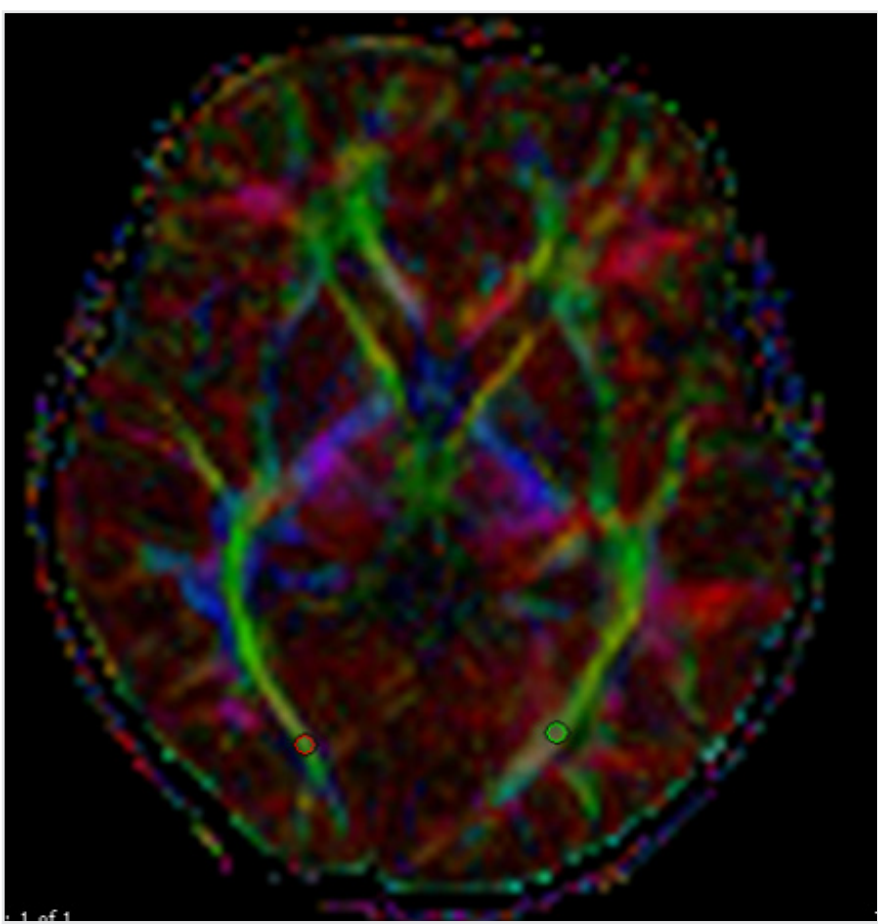

Figure 1. FA value is measured by placing ROI on bilateral optical radiation on the color FA map

ROI: Region of interest, FA: Fractional anisotropy
2- When the right and left optical radiation $M D$ and $A D$ values were compared with the control group, no significant difference was found.

3- Right and left optical radiation $\mathrm{RD}$ values were significantly higher than the healthy control group (respectively; $\mathrm{p}=0.001$, $\mathrm{p}=0.002)$.
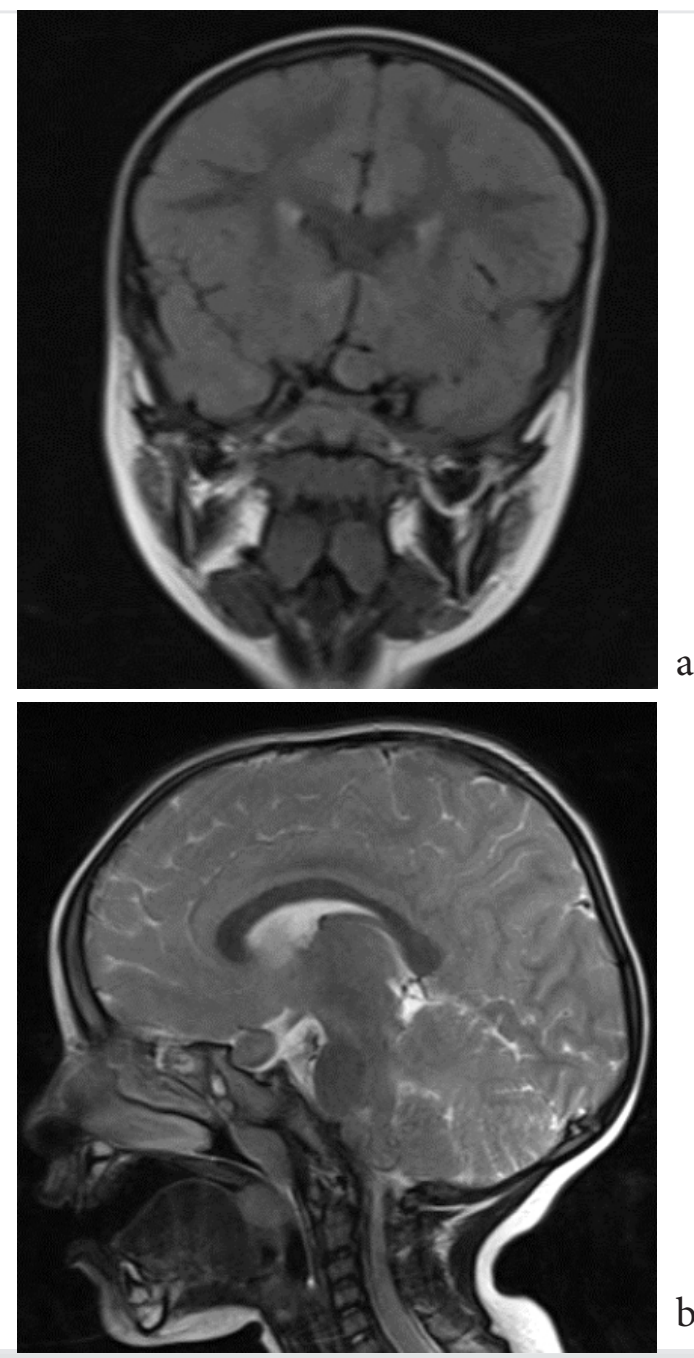

Figure 2. A seven-year-old patient with NF1 with optic glioma. Optic glioma is observed on the left side of the optic chiasm in coronal FLAIR (a) and sagittal T2 (b) images

Table 1. Optical radiation FA, MD, AD and RD values in patients with NF1 with and without optic glioma and in the healthy control group are presented in Table 1

\begin{tabular}{|c|c|c|c|c|c|c|c|c|}
\hline & \multicolumn{2}{|l|}{ OR FA } & \multicolumn{2}{|l|}{ OR_MD } & \multicolumn{2}{|l|}{ OR AD } & \multicolumn{2}{|l|}{ OR RD } \\
\hline & Right & Left & Right & Left & Right & Left & Right & Left \\
\hline Group 1 & $0.485 \pm 0.93$ & $0.474 \pm 0.102$ & $0.898 \pm 0.99$ & $0.929 \pm 0.152$ & $1.456 \pm 0.236$ & $1.467 \pm 0.363$ & $0.619 \pm 0.132$ & $0.660 \pm 0.088$ \\
\hline Control & $0.612 \pm 0.79$ & $0.602 \pm 0.82$ & $0.842 \pm 0.90$ & $0.854 \pm 0.77$ & $1.523 \pm 0.190$ & $1.533 \pm 0.158$ & $0.502 \pm 0.089$ & $0.514 \pm 0.102$ \\
\hline
\end{tabular}

OR: Optical radiation, Group 1: NF cases with optic glioma, Group 2: NF1 cases without optic glioma, FA: Fractional anisotropy, MD: Mean diffusity ( $x 10^{-3} \mathrm{~mm}^{2} / \mathrm{s}$ ), AD: Axial diffusity $\left(x 10^{-3} \mathrm{~mm}^{2} / \mathrm{s}\right), \mathrm{RD}$ : Radial diffusity $\left(\times 10^{-3} \mathrm{~mm}^{2} / \mathrm{s}\right)$ 
When group 1 and group 2 were compared;

1- No significant difference was found in terms of optical radiation $\mathrm{FA}$ values.

2- Right and left optical radiation $M D$ values were higher in group 1 ( $\mathrm{p}=0.02$ and $\mathrm{p}=0.05$, respectively).

3- No significant difference was found in terms of $A D$ values.

4- Left RD values were significantly higher in Group 1 ( $\mathrm{p}=0.003)$.

\section{Discussion}

Although OGs have a histologically benign nature, low proliferative potential and excellent survival results, they can cause serious problems that may result in irreversible blindness (5). It may affect the optic nerve or prechiasmatic area unilaterally or bilaterally in approximately one third of children with NF1 under the age of seven $(6,9,10)$. Symptoms may not be evident in the early stages of the disease. Findings such as obstructive hydrocephalus, sudden unexplained visual loss, nystagmus, visual field loss, and diencephalic syndrome may not always be observed in children with OG. The diagnosis is made in the early period by clinical and radiological findings $(5,6)$.

It is thought that the visual impairment observed in OG may be related to perineural or intraneural tumor growth and damage in the nerve's inner structure. Perineural growth occurs as a result of proliferation of astrocytes with some neural intratumor components without cystic changes, and fibrovascular arachnoidal trabeculae, mucinous and microcystic degeneration. Intraneural growth represents interaxial astrocytic proliferation and enlargement of fibrovascular trabeculae (5).

Management of OG is possible with careful evaluation of tumor-related parameters, including histological subtype, tumor location and extension, age, and presence of predisposing conditions, especially NF1 (5). Among the treatment options are observation, surgery and chemotherapy aimed at controlling tumor growth. Timing of treatment depends on tumor location and clinical features of other critical functional areas, visual disturbances due to $O G$, and treatment-related visual risks (5,10-12). Clinical follow-up and treatment decisions in children with NF1-related OG are made by MRI follow-up and ophthalmological examination (8). Vision loss in OGs can probably be explained by direct infiltration or pressure on the visual pathways by the tumor (8).

Although conventional MRI findings do not correlate with tumor size and visual loss, direct measurements of the integrity of the white matter tracts in the optic tract can better show visual loss. DTI can show the identification of all white matter tracts, including optic nerves, optic chiasm, optic tracts, and optic radiations, and whether they are affected at the cellular level (8).

DTI is an advanced imaging method that noninvasively evaluates cerebral white matter integrity and microstructural changes. Tissue anisotropy provides important information about axonal packaging, water-dependent membrane permeability, internal axon structure, degree of myelination, and general tissue water content $(13,14)$. The degree of tissue anisotropy is measured by FA. Axial diffusivity $(\mathrm{AD}, \lambda 1)$ measures the diffusion of water molecules parallel to the main axis of the axons and radial diffusivity (RD) (mean of $\lambda 2$ and $\lambda 3$ ) measures the diffusion of water molecules perpendicular to the main axis of the fibers. Increased $\mathrm{AD}$ indicates axonal damage, and increased RD is thought to be associated with myelin deficiency or damage $(28,29)$. Myelin loss and axonal damage occur as a result of a long-term disease process. Increased MD values in hamartomatous lesions in the brain seen in NF1 have been associated with histopathologically reported increased water accumulation, myelin vacuolation and spongiotic changes. Decreased FA and increased $\mathrm{AD}$ and $\mathrm{RD}$ values occur as a result of myelin and axonal damage $(13,14)$.

Evaluation of visual pathways using DTI is important in terms of analyzing the potential risk of visual loss (15). In recent years, it is thought that DTI parameters can be used as a biomarker in the evaluation of pathologies affecting the visual pathways such as optical radiation (15). Optical radiations transmit visual information from the lateral geniculate nucleus to the primary visual cortex. FA in the visual pathways have been associated with visual acuity or disorders such as optic neuritis, visual pathway tumors, prematurity, and optic neuropathy.

There are opinions that FA values can be used as a radiological biomarker in the evaluation of visual acuity in children with OG and can guide treatment (15). In a study, it was reported that there was a correlation between FA values and visual acuity loss in optical radiations of patients with NF1-related OG (8). Optical radiation $\mathrm{FA}$ values in subjects with abnormal visual acuity but no tumor involvement were significantly lower than those with normal visual acuity (8). Low FA values in optical radiations were associated with decreased visual acuity. In that study, it was emphasized that microstructural white matter integrity was more important than the number and density of fibers in the visual pathways (8). While white matter tract integrity in optic radiations was associated with loss of visual acuity, no changes in white matter integrity were observed in optic nerves and optic tract. Changes in optic radiation were reported in patients with OG in the anterior visual pathways $(8,16,17)$. In another study, decreased FA values in optic nerve and optic radiation were reported in patients with NF1 compared to healthy controls $(8,16)$. Lober et al. (17), on the other hand, found a decrease in the number of visual tracts in their study with a small number of patients, but they did not find a relationship between this decrease and visual acuity (18). In our study, optical radiation FA values in patients with NF1 with OG showed a significant decrease compared to the healthy control group, while MD and $\mathrm{RD}$ values were higher. Decreased FA and increased MD and $\mathrm{RD}$ values in the visual pathways in patients with NF1 were thought to be associated with the impairment of optic radiation at the microstructural level and myelin loss and demyelination. In addition, the increase in MD values in optic radiation in patients with NF1 with OG compared to healthy controls may be related to myelin vacuolation and spongiotic changes due to increased water accumulation reported in the histopathology 
of hamartomatous lesions. In patients with NF1 without OG, decreased FA and increased RD values were detected in optical radiation. These findings support the hypothesis that NF1 may be associated with microstructural damage in visual pathways independent of the presence of OG. There was no difference between the patients with NF1 with and without OG in terms of optical radiation FA values. This supports the hypothesis that changes similar to the myelin disorder reported in hamartomatous lesions seen in NF1 also develop in the visual pathways.

\section{Study Limitations}

Among the limitations of our study, first of all, small white matter structures of visual pathways such as optic nerves, optic chiasm, and optic tract were difficult to isolate on DTI maps due to the partial volume effect, and these regions were excluded from the study because these pathways were exposed to sensitivity artifacts. Our second limitation was the small number of patients with NF1 with OG. Our third limitation was that examination findings such as visual field and visual acuity in patients with NF1 were not included in our study.

\section{Conclusion}

As a result, it is obvious that there is microstructural damage in optic radiation, which is one of the visual pathways, in patients with NF1 with or without OG. Optical radiation FA values are thought to be related to the decrease in visual acuity during the follow-up period (8). Despite the variability in DTI parameters, extensive prospective studies are needed to determine the FA threshold value associated with visual loss and decreased visual acuity. The idea that changes in FA values detected in optical radiation in the visual pathways in patients with NF1 can be predicted in the early stages of visual impairment is promising in terms of treatment planning and management.

\section{Ethics}

Ethics Committee Approval: 2020-10288.

Peer-review: Externally peer reviewed.

Financial Disclosure: The author declared that this study received no financial support.

\section{References}

1. Campen CJ, Gutmann DH. Optic Pathway Gliomas in Neurofibromatosis Type 1. J Child Neurol 2018;33:73-81.

2. Hales PW, Smith V, Dhanoa-Hayre D, O'Hare P, Mankad K, d'Arco $\mathrm{F}$, et al. Delineation of the visual pathway in paediatric optic pathway glioma patients using probabilistic tractography, and correlations with visual acuity. Neuroimage Clin 2017 Oct 11;17:541-8.

3. Avery RA, Mansoor A, Idrees R, Trimboli-Heidler C, Ishikawa H, Packer RJ, et al. Optic pathway glioma volume predicts retinal axon degeneration in neurofibromatosis type 1. Neurology 2016;87:240327.

4. Ho CY, Deardorff R, Kralik SF, West JD, Wu YC, Shih CS. Comparison of multi-shot and single shot echo-planar diffusion tensor techniques for the optic pathway in patients with neurofibromatosis type 1. Neuroradiology 2019;61:431-41.

5. Dotto PF, Berezovsky A, Cappellano AM, da Silva NS, Sacai PY, Adolfo F, et al. Visual function assessed by visually evoked potentials in optic pathwaylow-gradegliomaswithand with outneuro fibromatosis t33ype 1. DocOphthalmol2018;136:177-89.

6. Friedrich RE, Nuding MA. Optic Pathway Glioma and Cerebral Focal Abnormal Signal Intensity in Patients with Neurofibromatosis Type 1: Characteristics, Treatment Choices and Follow-up in 134 Affected Individuals and a Brief Review of the Literature. Anticancer Res 2016;36:4095-121.

7. Segal L, Darvish-Zargar M, Dilenge ME, Ortenberg J, Polomeno RC. Optic pathway gliomas in patients with neurofibromatosis type 1: follow-up of 44 patients. J AAPOS 2010;14:155-8.

8. deBlank PM, Berman JI, Liu GT, Roberts TP, Fisher MJ. Fractional anisotropy of the optic radiations is associated with visual acuity loss in optic pathway gliomas of neurofibromatosis type 1. Neuro Oncol 2013;15:1088-95.

9. GuerreiroStucklin AS, Tabori U, Grotzer MA. The changing landscape of pediatric low-grade gliomas: clinical challenges and emerging therapies. Neuropediatrics 2016;47:70-83.

10. Fried I, Tabori U, Tihan T, Reginald A, Bouffet E. Optic pathway gliomas: a review. CNS Oncol 2013;2:143-59.

11. Louis DN, Perry A, Reifenberger G, von Deimling A, FigarellaBranger D, Cavenee WK, et al. The 2016 World Health Organization Classification of Tumors of the Central Nervous System: a summary. Acta Neuropathol 2016;131:803-20.

12. Khafaga Y, Hassounah M, Kandil A, Kanaan I, Allam A, El Husseiny $\mathrm{G}$, et al. Optic gliomas: a retrospective analysis of 50 cases. Int J Radiat Oncol Biol Phys 2003;56:807-12.

13. Ertan G, Zan E, Yousem DM, Ceritoglu C, Tekes A, Poretti A, et al. Diffusion tensor imaging of neurofibromatosis bright objects in children with neurofibromatosis type 1. Neuroradiol J 2014;27:61626.

14. Van Engelen SJPM, Krab LC, Moll HA, Goede-Bolder A de, Pluijm SMF, Catsman-Berrevoets CE, et al. Quantitative differentiation between healthy and disordered brain matter in patients with neurofibromatosis type I using diffusion tensor imaging. AJNR Am J Neuroradiol 2008;29:816-22.

15. De Blank P, Fisher MJ, Gittleman H, Barnholtz-Sloan JS, Badve C, Berman JI. Validation of an automated tractography method for the opticradiations as a biomarker of visual acuity in neurofibromatosisassociated optic pathway glioma. Exp Neurol 2018;299:308-16.

16. Filippi CG, Bos A, Nickerson JP, Salmela MB, Koski CJ, Cauley KA. Magnetic resonance diffusion tensor imaging (MRDTI) of the optic nevre and optic radiations at $3 \mathrm{~T}$ in children with neurofibromatosis type I (NF-1). Pediatr Radiol 2012;42:168-74.

17. Lober RM, Guzman R, Cheshier SH, Fredrick DR, Edwards MS, Yeom KW. Application of diffusion tensor tractography in pediatric optic pathway glioma. J Neurosurg Pediatr 2012;10:273-80. 